\title{
Perbedaan Konsumsi Pangan dan Asupan Gizi pada Balita Stunting dan Normal di Lima Provinsi di Indonesia
}

\section{Differences in Food Consumption and Nutrient Intake of Stunting and Normal Toddlers in Five Provinces in Indonesia}

\author{
Mariana Prijono $^{1)^{*}}$, Nuri Andarwulan ${ }^{2,3)}$, dan Nurheni Sri Palupi ${ }^{2,3)}$ \\ ${ }^{1)}$ Program Studi Magister Teknologi Pangan, Sekolah Pascasarjana, Institut Pertanian Bogor, Bogor \\ ${ }^{2)}$ Departemen Ilmu dan Teknologi Pangan, Fakultas Teknologi Pertanian, Institut Pertanian Bogor, Bogor \\ ${ }^{3)}$ South East Asian Food and Agricultural Science and Technology Center, Institut Pertanian Bogor, Bogor
}

\begin{abstract}
Stunting is an important sign of chronic malnutrition that exists in early life with greater infection risk and with many long-term effects, including the need for physical work. Stunting is a problem for the Indonesian people to produce a generation that has global competitiveness. In general, this study aims to determine the effect of food consumption on the adequacy and balance of nutrition between stunted and normal children in 5 provinces in Indonesia. Specifically, this study aims to (1) lassify toddlers based on height according to age in the stunting and normal categories, (2) get a profile of stunting and normal toddler food consumption, (3) analyze data on nutrient intake and food contribution in the stunting group and normal, (4) analyze data on the adequacy and balance of nutrition from food intake in stunting and normal children under five in 5 provinces in Indonesia. This study used secondary data of food consumption data from SKMI 2014 and anthropometric data from Riskesdas 2013 of West Java, Central Java, East Java, West Nusa Tenggara and East Nusa Tenggara provinces. There were 2,039 samples from 5 provinces, $38.4 \%$ of them were stunting toddlers. Food consumption of toddlers with normal height was higher than stunting toddlers for eggs and egg products and lower for sugars. Intake of calcium and vitamin A in normal toddlers was significantly higher than stunting toddlers and lower for vitamin C. Both stunting and normal children groups showed deficiency, sufficiency and excess in nutrient intake. Imbalance nutrient intake for both stunting and normal children reached $100 \%$.
\end{abstract}

Keywords: consumption, food, nutritional intake stunting, toddler

\begin{abstract}
Abstrak. Stunting adalah tanda penting dari malnutrisi kronis yang ada pada awal kehidupan dengan risiko infeksi yang lebih besar dan dengan banyak efek jangka panjang, termasuk kebutuhan akan pekerjaan fisik. Pengerdilan adalah masalah bagi masyarakat Indonesia untuk menghasilkan generasi yang memiliki daya saing global. Secara umum, penelitian ini bertujuan untuk mengetahui pengaruh konsumsi pangan terhadap kecukupan dan keseimbangan gizi antara balita stunting dan normal di 5 provinsi di Indonesia. Secara khusus, penelitian ini bertujuan untuk (1) mengelompokkan balita berdasarkan tinggi badan menurut usia dalam kategori stunting dan normal, (2) mendapatkan profil konsumsi pangan balita stunting dan normal, (3) menganalisis data asupan zat gizi dan kontribusi pangan pada kelompok stunting dan normal, (4) menganalisis data kecukupan dan keseimbangan gizi dari pangan pada balita stunting dan normal di 5 provinsi di Indonesia. Penelitian ini menggunakan data sekunder data konsumsi makanan dari SKMI 2014 dan data antropometrik dari Riskesdas 2013 provinsi Jawa Barat, Jawa Tengah, Jawa Timur, Nusa Tenggara Barat, dan Nusa Tenggara Timur. Ada 2.039 contoh dari 5 provinsi, 38.4\% di antaranya adalah balita stunting. Konsumsi balita dengan tinggi normal lebih tinggi daripada stunting balita untuk telur dan produk telur dan lebih rendah untuk gula. Asupan kalsium, vitamin A pada balita normal secara signifikan lebih tinggi daripada stunting balita dan lebih rendah untuk vitamin C. Status gizi kurang, cukup, dan berlebih terdapat pada balita stunting dan normal. Asupan gizi yang tidak seimbang pada balita stunting dan normal mencapai $100 \%$.
\end{abstract}

Kata Kunci: asupan gizi, balita, konsumsi, pangan, stunting

Aplikasi Praktis. Penelitian ini memberikan gambaran status gizi balita berkaitan dengan stunting konsumsi pangan, asupan zat gizi, kontribusi pangan terhadap pemenuhan zat gizi, dan kecukupan pangan dan keseimbangan pangan di Indonesia guna merumuskan kebijakan penanggulangan masalah stunting di Indonesia.

Korespondensi: mariana.prijono@gmail.com 


\section{PENDAHULUAN}

Stunting adalah kondisi gagal tumbuh pada balita balita (bayi di bawah lima tahun) akibat dari kekurangan gizi kronis sehingga balita terlalu pendek untuk usianya. Kekurangan gizi terjadi sejak bayi dalam kandungan, dan pada masa awal setelah bayi lahir akan tetapi kondisi stunting baru nampak setelah bayi berusia 2 tahun. Menurut Kemenkes 2020, balita dikategorikan stunting jika nilai simpangan panjang badan $(\mathrm{PB} / \mathrm{U})$ atau tinggi badan $(\mathrm{TB} / \mathrm{U})$ menurut umurnya dibandingkan dengan standar baku antropometri balita (z score) antara -2SD/standar deviasi dan -3SD (pendek) dan kurang dari -3SD (sangat pendek). Hasil kegiatan riset kesehatan dasar pada tahun 2013 menunjukkan bahwa prevalensi stunting menurun dari $37.3 \%$ menjadi $30.8 \%$ pada tahun 2018 (Kemenkes 2013a, 2018). Meskipun demikian prevalensi stunting masih tergolong tinggi yang menunjukkan adanya pertumbuhan yang kurang maksimal pada sekitar satu dari tiga balita di Indonesia.

Stunting disebabkan oleh faktor multi dimensi dan tidak hanya disebabkan oleh faktor gizi buruk yang dialami oleh ibu hamil maupun balita balita. Intervensi yang paling menentukan untuk dapat mengurangi pervalensi stunting oleh karenanya perlu dilakukan pada 1.000 Hari Pertama Kehidupan (HPK) dari balita balita. Beberapa faktor yang menjadi penyebab stunting (WHO 2014) adalah praktek pengasuhan yang kurang baik, termasuk kurangnya pengetahuan ibu mengenai kesehatan dan gizi sebelum dan pada masa kehamilan, serta setelah ibu melahirkan; masih terbatasnya layanan kesehatan termasuk layanan Ante Natal Care, Post Natal Care dan pembelajaran dini yang berkualitas; masih kurangnya akses rumah tangga/keluarga ke makanan bergizi; dan kurangnya akses ke air bersih serta sanitasi. Penelitian pada balita di Mozambique menunjukkan bahwa berat lahir, status pendidikan ibu, pekerjaan ibu, tinggal di daerah pedesaan, jumlah balita balita, jumlah orang dalam satu keluarga, memasak dengan arang, menghuni perumahan kayu atau jerami atau perumahan tanpa lantai yang layak, durasi menyusui secara keseluruhan serta durasi menyusui eksklusif, dan waktu dimulainya pemberian makanan pelengkap secara signifikan terkait dengan stunting (Cruz et al. 2017). Penelitian stunting di Etiopia oleh Motbainor et al. (2015) menyimpulkan strategi intervensi malnutrisi balita harus difokuskan tidak hanya pada program ketahanan pangan tetapi juga pada keanekaragaman produk pertanian yang merupakan elemen dasar keanekaragaman makanan dan bahan makanan untuk menyediakan makanan bergizi dan seimbang untuk balita. Selain intervensi ketahanan pangan dan aksi keanekaragaman pangan untuk nutrisi balita, jumlah makanan yang dimakan balita per hari membutuhkan perhatian khusus. Untuk pemberian makan balita yang benar dan memberikan jumlah makanan optimal per hari serta keanekaragaman pangan dibutuhkan pengetahuan tentang gizi sehingga kampanye gizi sangat diperlukan.

Dalam upaya mengatasi stunting pemerintah membentuk Tim Nasional Percepatan Penanggulangan
Kemiskinan (TNP2K) yang merekomendasikan rencana aksi untuk menangani masalah stunting. Rencana aksi dilakukan dalam waktu empat tahun dengan memaksimalkan program terkait stunting di $100 \mathrm{kota} / \mathrm{kabupaten}$ untuk tahun 2018, dan akan diperluas menjadi 160, 390 dan 514 kota/kabupaten di tahun 2019, 2020 dan 2021 (TNP2K 2017). Pemilihan 100 kabupaten/kota didasarkan atas kriteria jumlah dan prevalensi balita stunting, yang dibobot dengan tingkat kemiskinan provinsi. Pada penelitian ini dipilih 5 provinsi dengan jumlah kota/ kabupaten yang merupakan prioritas terbanyak yang dipilih oleh TNP2K, yaitu Jawa Barat (13 kota/kabupaten), Jawa Tengah (11 kota/kabupaten), Jawa Timur (11 kota/kabupaten), NTT (13 kota/kabupaten) dan NTB (6 kota/kabupaten).

Secara umum, penelitian ini bertujuan untuk mengetahui pengaruh konsumsi pangan terhadap kecukupan dan keseimbangan gizi antara balita stunting dan normal di 5 provinsi di Indonesia. Secara khusus, penelitian ini bertujuan untuk (1) mengelompokkan balita berdasarkan tinggi badan menurut usia dalam kategori stunting dan normal, (2) mendapatkan profil konsumsi pangan balita stunting dan normal, (3) menganalisis data asupan zat gizi dan kontribusi pangan pada kelompok stunting dan normal, (4) menganalisis data kecukupan dan keseimbangan gizi dari pangan pada balita stunting dan normal di 5 provinsi di Indonesia.

\section{BAHAN DAN METODE}

\section{Bahan}

Penelitian menggunakan data sekunder dari kegiatan Riskesdas tahun 2013 dan SKMI tahun 2014 untuk kelompok balita yang diperoleh dari Badan Penelitian dan Pengembangan Kesehatan Kementerian (Balibangkes) RI. Variabel yang digunakan mengacu pada kuesioner rumah tangga dan kuesioner konsumsi individu SDT 2014. Sebanyak tiga rumah-tangga (10\%) di masing-masing BS dipilih secara acak sistematik untuk dilakukan kunjungan kedua kali dalam rangka food recall 1x 24 jam pada hari yang tidak berurutan.

Penelitian ini dilakukan dalam enam tahap seperti diuraikan berikut ini. Permintaan data antropometri Riskesdas 2013 dan SKMI 2014 serta data konsumsi pangan SKMI 2014 untuk kelompok umur 0-60 bulan ke Balitbangkes RI.

\section{Ekstraksi data SKMI 2014}

Ekstraksi data SKMI 2014 meliputi identifikasi data antropometri berupa status gizi balita berdasarkan tinggi badan menurut umur, identifikasi kategori pangan, dan pengelompokan wilayah. Identifikasi kategori pangan berdasarkan 17 kelompok pangan sesuai dengan pengelompokan pangan ASEAN, yaitu serealia dan olahannya; umbi, batang berpati dan olahannya; kacang, biji dan olahannya; sayuran dan olahannya, buah dan olahannya; daging dan olahannya; jeroan, non daging dan olahannya; ikan, hewan laut lainnya, dan olahannya; telur dan olahannya; susu dan olahannya; minyak dan 
lemak, gula, sirup dan konfeksioneri; bumbu dan olahannya; minuman dan olahannya; makanan komposit (franchise food); air; suplemen dan jamu/herbal (ASEAN 2014). Pengelompokan wilayah dikelompokkan berdasarkan provinsinya, yaitu provinsi Jawa Barat, Jawa Tengah, Jawa Timur, NTT dan NTB.

\section{Perhitungan profil konsumsi pangan}

Profil konsumsi pangan mencakup identifikasi jenis pangan dan jumlah pangan yang dikonsumsi balita yang diketahui dari ekstraksi data SKMI 2014. Asupan gizi dari pangan yang dianalisis pada penelitian ini meliputi energi, karbohidrat, protein, lemak, kalsium, natrium, zat besi, vitamin $\mathrm{A}$, dan vitamin $\mathrm{C}$. Nilai gizi dari masing-masing bahan pangan diperoleh dari Tabel Konsumsi Pangan Indonesia (TKPI) 2019, ASEAN Food Composition Database (AFCD) 2014, Buku Studi Diet Total (Kemenkes 2014), Nutrisurvey 2007, dan informasi label pangan olahan. Perhitungan asupan zat gizi dilakukan dengan mengalikan profil konsumsi dengan kandungan gizi dari pangan yang dikonsumsi.

\section{Analisis kecukupan pangan}

Analisis data dilakukan untuk mengetahui pemenuhan kecukupan gizi kelompok umur 0-60 bulan. Analisis pemenuhan kecukupan gizi mengacu pada rekomen-dasi pemenuhan gizi sesuai anjuran WHO dan Dewey 2001. Pemenuhan gizi dari pangan dihitung dengan tahapan berikut:

1. Mencari kebutuhan gizi 0-60 bulan (A): rekomendasi pemenuhan gizi WHO x AKG.

2. Mencari asupan gizi (B): jumlah pangan yang dikonsumsi $\mathrm{x}$ kandungan gizi pangan.

3. Mencari persentase pemenuhan kebutuhan gizi (Mc Crory dan Campbell 2011): asupan zat gizi (B)/ rekomendasi pemenuhan gizi WHO (A). Persentase pemenuhan dikategorikan berdasarkan kecukupan gizi: kurang jika $<80 \%$, cukup jika $80-120 \%$, lebih jika $>120 \%$.

\section{Analisis keseimbangan zat gizi}

Analisis keseimbangan zat gizi dilakukan dengan pengelompokkan data balita stunting dan normal dengan melihat asupan zat gizi pada masing-masing contoh. Balita yang masuk dalam kategori gizi seimbang adalah balita yang kecukupan asupan zat gizi cukup dan berlebih untuk parameter zat gizi energi, karbohidrat, protein, lemak, kalsium, natrium, zat besi, vitamin A dan vitamin C. Balita gizi tidak seimbang jika kecukupan salah satu dari parameter asupan zat gizi di atas termasuk dalam kategori kurang.

\section{Analisis data}

Analisis statistik menggunakan software SPSS versi 26 tahun 2019 dengan membandingkan rerata konsumsi pangan dan asupan zat gizi (energi, karbohidrat, protein, lemak, kalsium, natrium, zat besi, vitamin A, vitamin C) pada balita stunting dan normal menggunakan uji $\mathrm{T}$.

\section{HASIL DAN PEMBAHASAN}

\section{Distribusi jumlah sampel balita balita menurut umur pada SKMI 2014}

Survei Konsumsi Makanan Individu (SKMI) 2014 yang dilakukan pada 34 provinsi di Indonesia diperoleh data balita sebanyak 6.093 balita. Dengan komposisi kelompok umur 1 tahun sampai 5 tahun lebih banyak (79.78\%) dibandingkan dengan balita usia 1 tahun ke bawah $(20.22 \%)$.

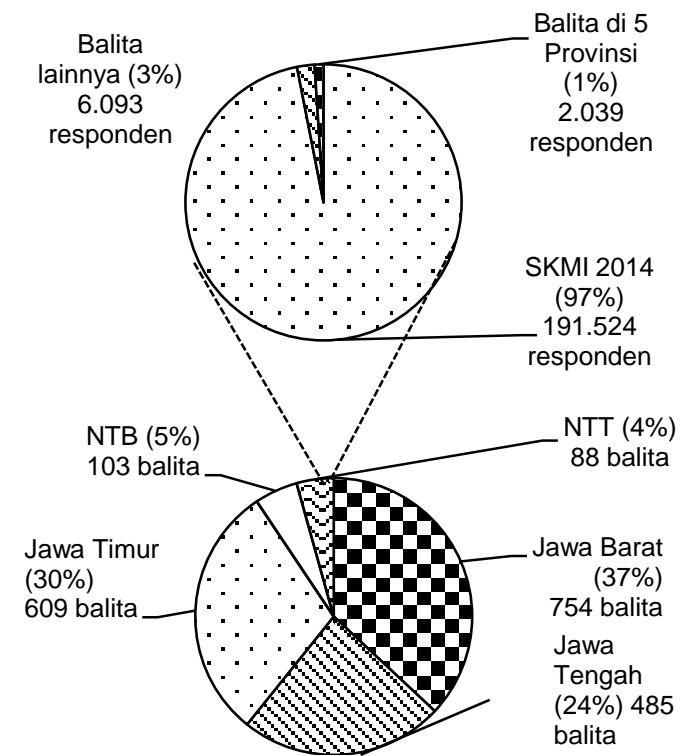

Gambar 1. Balita pada 5 provinsi menurut SKMI 2014

Gambar 1 menunjukkan jumlah balita sebanyak 6.093 contoh atau sekitar 3\% dari keseluruhan data SKMI 2014. Data pada 5 provinsi ini mencakup $33.46 \%$ yaitu sebanyak 2.039 contoh dari keseluruhan data balita pada SKMI 2014.

\section{Profil status gizi balita balita pada 5 provinsi}

Menurut Keputusan Menteri Kesehatan Nomor 1995/MENKES/SK/XII/2010 tentang Standar Antropometri Penilaian Status Gizi Balita, pengertian pendek dan sangat pendek adalah status gizi yang didasarkan pada indeks Panjang Badan menurut Umur (PB/U) atau Tinggi Badan menurut Umur (TB/U) yang merupakan padanan istilah stunted (pendek) dan severely stunted (sangat pendek) (Kemenkes 2020). Menurut Riskesdas 2013, untuk kategori pendek dan sangat pendek dapat disebut sebagai balita stunting (Kemenkes 2013b).

Gambar 2 menunjukkan dari 5 provinsi terdapat 783 balita mengalami stunting, yaitu $38.4 \%$ dari jumlah contoh. Jika dilihat dari provinsi Jawa Barat, Jawa Tengah, dan Jawa Timur ada 1 balita stunting diantara 3 balita. Pada provinsi NTT dan NTB ada 1 balita stunting diantara 2 balita. Lebih jauh dapat dilihat balita stunting (44 contoh) di NTT jumlahnya lebih banyak daripada balita normal (43 contoh), yaitu sebesar $50.6 \%$ balita stunting. 


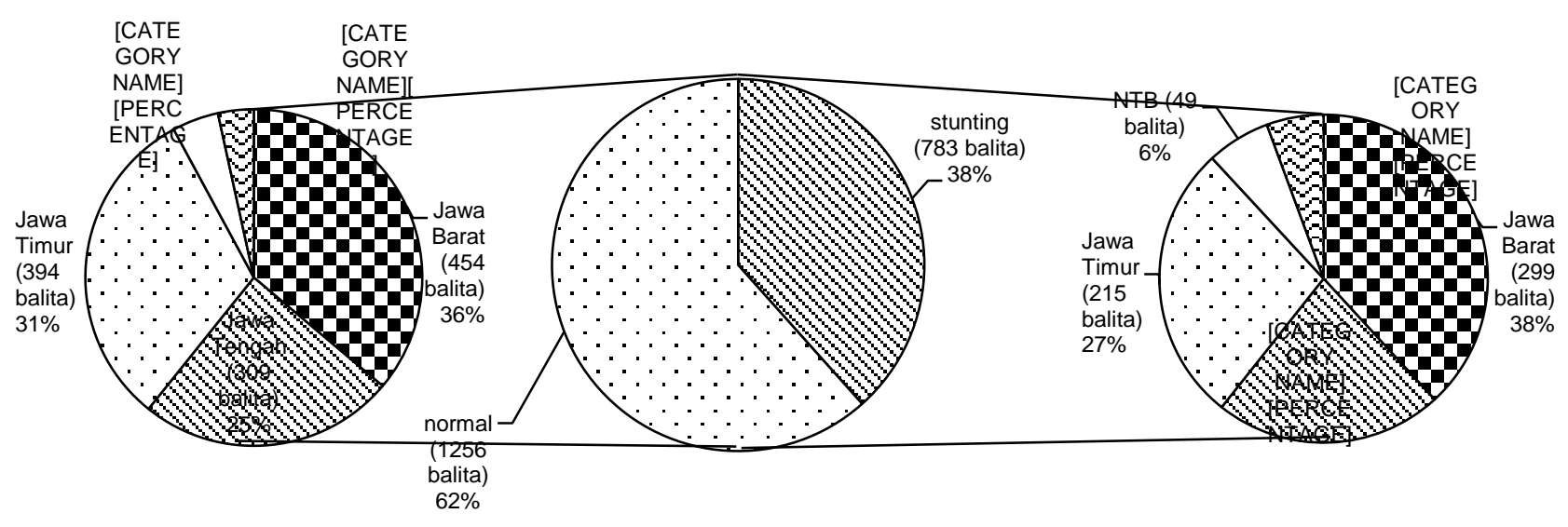

Gambar 2. Status tinggi badan pada 5 provinsi

\section{Konsumsi pangan pada balita di 5 provinsi}

Konsumsi pangan pada balita di 5 provinsi dari data SKMI 2014 ada 734 jenis pangan, baik berupa makanan maupun minuman. Jenis pangan yang diperoleh ini dikelompokkan menjadi 12 kelompok pangan. Total konsumsi pangan pada penelitian ini adalah 326.79 g/orang/hari pada balita stunting dan $329.29 \mathrm{~g} / \mathrm{orang} / \mathrm{hari}$ pada balita normal. Hal ini didukung dengan data dari South East Asia Nutrition Surveys (SEANUTS) 20112012 pada penelitian Valentina (2014) yang menyatakan total konsumsi balita usia 1-12 tahun adalah 440, 45 g/orang/hari. Rata-rata konsumsi pangan (g/kapita/hari) yang paling tinggi adalah serealia dan hasil olahannya diikuti oleh susu dan hasil olahannya. Pada balita balita hal tersebut wajar, karena balita-balita biasanya diberi ASI, susu formula dan susu pertumbuhan, sedangkan serealia adalah MPASI pada bayi yang selanjutnya diganti menjadi nasi yang merupakan makanan pokok di Indonesia.

Pada Tabel 1 dapat dilihat konsumsi telur dan gula pada balita stunting dan normal berbeda secara signifikan. Konsumsi telur sebanyak $24.62 \mathrm{~g} / \mathrm{orang}$ /hari pada balita stunting lebih rendah dibandingkan pada balita normal yaitu sebanyak 28.48 g/orang/hari. Hasil ini sesuai dengan penelitian yang dilakukan di Provinsi Cotopaxi, Ekuador, oleh Iannotti et al. (2017) pada balita usia 6 hingga 9 bulan antara kelompok balita yang mengonsumsi telur (1 telur per hari selama 6 bulan) dan menunjukkan penurunan prevalensi stunting sebesar 47\%. Balita dalam kelompok perlakuan memiliki asupan telur yang lebih tinggi dan mengurangi asupan gula dibandingkan dengan kontrol.

Konsumsi gula pada balita di 5 provinsi juga menunjukkan hasil yang berbeda secara signifikan $(p=0,08)$. Balita stunting mengonsumsi gula lebih banyak (14.83 g/orang/hari) dari pada balita normal (11.67g/orang/hari). O'Neil et al. (2011) pada penelitiannya menggunakan data National Health and Nutrition Examination Survey (NHANES) 1999-2004 diketahui konsumsi permen pada balita usia 2-13 tahun di Amerika Serikat adalah $11.4 \mathrm{~g} /$ orang/hari.

Selain telur dan gula yang signifikan berbeda, kelompok pangan lainnya juga cenderung berbeda, seperti serealia, umbi, daging dan ikan (Tabel 1). Konsumsi serealia dan umbi serta ikan pada balita stunting cenderung lebih tinggi daripada balita normal. Kandungan gizi terbesar dari ketiga kategori serealia dan umbi adalah karbohidrat, sedangkan pada ikan dan daging kandungan gizi yang besar adalah protein.

Tabel 1. Perbandingan konsumsi pangan pada balita stunting dan normal di 5 provinsi dari data SKMI 2014

\begin{tabular}{lccc}
\hline \multirow{2}{*}{ Kelompok Pangan } & \multicolumn{2}{c}{ Rata-rata Konsumsi (g/orang/hari) } & \\
\cline { 2 - 3 } & $\begin{array}{c}\text { Stunting } \\
(\mathbf{n}=782)\end{array}$ & $\begin{array}{c}\text { Normal } \\
(\mathbf{n}=1257)\end{array}$ & \\
\hline Serelia & $72.44 \pm 52.66$ & $68.73 \pm 45.80$ & 0.09 \\
Umbi & $13.62 \pm 43.08$ & $11.75 \pm 31.56$ & 0.29 \\
Kacang & $24.27 \pm 38.89$ & $26.66 \pm 42.79$ & 0.20 \\
Sayur & $13.83 \pm 23.60$ & $12.90 \pm 22.94$ & 0.38 \\
Buah & $17.78 \pm 41.89$ & $15.54 \pm 37.84$ & 0.22 \\
Daging & $33.49 \pm 52.46$ & $36.47 \pm 59.54$ & 0.24 \\
Jeroan & $1.79 \pm 15.44$ & $2.06 \pm 11.78$ & 0.66 \\
Ikan & $28.31 \pm 65.59$ & $25.90 \pm 68.40$ & 0.43 \\
Telur & $24.62 \pm 36.20$ & $28.47 \pm 37.79$ & $0.02^{*}$ \\
Susu & $63.23 \pm 119.17$ & $71.20 \pm 112.09$ & 0.13 \\
Minyak & $15.61 \pm 15.83$ & $14.33 \pm 13.84$ & 0.06 \\
Gula & $14.83 \pm 30.06$ & $11.68 \pm 23.55$ & $0.01^{*}$ \\
Bumbu & $2.62 \pm 2.62$ & $2.71 \pm 5.21$ & 0.64 \\
Minuman & $42.10 \pm 92.12$ & $38.81 \pm 95.94$ & 0.44 \\
Makanan komposit & $0.25 \pm 4.24$ & $0.64 \pm 8.64$ & 0.17 \\
Air & $651.78 \pm 456.39$ & $657.54 \pm 422.01$ & 0.77 \\
Suplemen & $0.1 \pm 2.42$ & $0.27 \pm 2.88$ & 0.16 \\
\hline Jumlah & 1020.67 & 1025.52 & \\
Jumlah tanpa air dan & 326.79 & 329.29 & 0.71 \\
minuman & & &
\end{tabular}

Keterangan: *Rata-rata konsumsi antara balita stunting dan normal berbeda secara signifikan $(p<0.05)$

\section{Asupan zat gizi dan kontribusi zat gizi pada} konsumsi balita di 5 provinsi

Asupan zat gizi makro pada balita stunting dan normal tidak menunjukkan adanya beda signifikan (Tabel 2). Walaupun asupan zat gizi makro tidak signifikan berbeda antara kedua kelompok, namun terlihat asupan energi dan karbohidrat pada balita stunting sedikit lebih tinggi, sedangkan asupan protein dan lemak lebih rendah. Asupan zat gizi mikro terdapat perbedaan signifikan pada asupan kalsium, vitamin A dan vitamin C. Asupan kalsium dan vitamin A pada balita stunting lebih rendah daripada balita normal. Perbedaan asupan gizi pada balita stunting dan normal disebabkan oleh jenis pangan yang dikomsumsi. 
Asupan kalsium menunjukkan adanya perbedaan yang signifikan pada balita normal $634.73 \mathrm{mg} /$ orang/hari lebih tinggi daripada balita stunting sebanyak 581.99 $\mathrm{mg} / \mathrm{orang} / \mathrm{hari}$. Kontribusi pangan yang paling tinggi terhadap asupan kalsium adalah dari susu, tetapi tidak ada perbedaan signifikan asupan kalsium dari susu pada balita normal dan balita stunting (Tabel 3). Sejalan dengan penelitian sebelumnya yang dilakukan oleh Gibson et al. (2007) di Thailand, Mikhail et al. (2013) di Mesir, Stuijvenberg et al. (2015) di Afrika Selatan, dan Sari et al. (2018) di Pontibalita diketahui bahwa asupan kalsium signifikan lebih rendah pada balita stunting dibandingkan balita normal. Asupan kalsium balita stunting usia 6-59 bulan di Pontibalita 343.91 mg/orang/hari sedangkan pada balita normal 707.97 $\mathrm{mg} /$ orang/hari (Sari et al. 2018). Risiko stunting 3.93 kali lebih besar pada balita dengan asupan kalsium rendah (Burckhardt et al. 2010).

Tabel 2. Perbandingan asupan zat gizi pada balita balita stunting dan normal di 5 provinsi

\begin{tabular}{lccc}
\hline \multirow{2}{*}{ Zat Gizi } & \multicolumn{2}{c}{$\begin{array}{c}\text { Rata-rata Asupan Zat Gizi } \\
\text { (per orang per hari) }\end{array}$} & \multirow{2}{*}{ Nilai $\boldsymbol{p}$} \\
\cline { 2 - 3 } & Stunting $(\mathbf{n}=\mathbf{7 8 2})$ & Normal $(\mathbf{n}=\mathbf{1 2 5 7})$ & \\
\hline Energi (kkal) & $1347.99 \pm 407.93$ & $1334.09 \pm 424.65$ & 0.47 \\
Karbohidrat $(\mathrm{g})$ & $195.40 \pm 71.45$ & $189.03 \pm 74.07$ & 0.06 \\
Protein $(\mathrm{g})$ & $43.43 \pm 19.76$ & $45.03 \pm 21.64$ & 0.09 \\
Lemak $(\mathrm{g})$ & $46.10 \pm 21.91$ & $47.46 \pm 21.53$ & 0.17 \\
Kalsium $(\mathrm{mg})$ & $581.99 \pm 529.96$ & $634.86 \pm 550.80$ & $0.03^{*}$ \\
Natrium $(\mathrm{mg})$ & $2002.30 \pm 1586.56$ & $1895.03 \pm 2163.89$ & 0.23 \\
Zat Besi $(\mathrm{mg})$ & $13.46 \pm 21.64$ & $14.61 \pm 22.83$ & 0.26 \\
Vitamin A $(\mathrm{mcg})$ & $524.40 \pm 770.03$ & $664.21 \pm 949.89$ & $0.00^{*}$ \\
Vitamin C $(\mathrm{mg})$ & $77.14 \pm 195.63$ & $52.54 \pm 111.77$ & $0.00^{*}$ \\
\hline Keterangan: ${ }^{*}$ Rata-rata asupan zat gizi antara balita stunting dan \\
normal berbeda secara signifikan $(p<0.05)$ & & \\
\end{tabular}

Kontribusi vitamin A dari daging dan telur pada balita normal lebih tinggi daripada stunting, sedangkan vitamin A dari ikan lebih tinggi asupannya pada balita stunting dari pada normal. Ssentongo et al. (2020) pada penelitiannya menemukan ada hubungan yang signifikan dari kekurangan vitamin A dengan kegagalan pertumbuhan linear pada balita-balita prasekolah di Uganda. Vitamin A berfungsi untuk mengatur gen dan sekresi hormon pertumbuhan, menjaga integritas struktural dan fungsional sel epitel mukosa, termasuk saluran pencernaan.
Asupan vitamin $\mathrm{C}$ pada balita normal dan stunting berbeda nyata dengan asupan vitamin $\mathrm{C}$ yang lebih tinggi pada balita stunting daripada balita normal. Asupan pada balita normal $52.52 \mathrm{mg} /$ orang/hari, sedangkan pada balita stunting adalah 77.14 $\mathrm{mg} / \mathrm{balita} /$ hari. Jika dilihat dari konsumsi pangannya, diketahui bahwa kontribusi vitamin $\mathrm{C}$ lebih tinggi secara signifikan pada balita stunting dibandingkan dengan normal dari konsumsi sayur dan minuman. Hal ini sesuai dengan konsumsi pangan kelompok sayur dan minuman pada balita stunting lebih tinggi daripada balita normal. Perbedaan kontribusi vitamin C pada balita stunting dan normal dari sayur kecil, sedangkan dari minuman sangat besar. Hal ini menunjukkan balita stunting mengonsumsi minuman dalam jumlah yang banyak. Kelompok minuman yang paling banyak dikonsumi oleh balita stunting adalah jenis minuman berperisa dengan penambahan vitamin $\mathrm{C}$ cukup tinggi tetapi asupan zat gizi mikro lainnya tidak dijumpai.

\section{Kecukupan zat gizi makro dan mikro pada balita di 5 provinsi Indonesia}

Pada Tabel 4 disajikan kecukupan gizi berlebih, cukup dan kurang dari energi, karbohidrat, protein dan lemak pada balita stunting dan normal di 5 provinsi. Secara keseluruhan kecukupan zat gizi pada balita normal maupun stunting menunjukkan adanya kekurangan zat gizi. Sehingga tidak dapat dikatakan bahwa hanya balita stunting yang mengalami kekurangan asupan zat gizi.

Kecukupan energi yang kurang dialami oleh $23.7 \%$ (483 balita), sedangkan kurang asupan karbohidrat dialami oleh $36.7 \%$ (748 balita), kurang asupan protein $3.7 \%$ (75 balita), dan $33.7 \%$ (688 balita) kurang asupan lemak. Untuk asupan energi yang kurang mencapai 25.83\% (202 balita stunting) dari jumlah contoh stunting, sedangkan karbohidrat yang kurang mencapai 20.84\% (163 balita stunting), dan lemak yang kurang mencapai $36.06 \%$ (282 balita stunting). Untuk mengatasi asupan energi yang kurang dapat dilakukan dengan konsumsi makanan yang mengandung karbohidrat dan lemak. Kekurangan asupan lemak pada balita dapat menyebabkan penyerapan vitamin $\mathrm{A}, \mathrm{D}, \mathrm{E}$ dan $\mathrm{K}$ menjadi kurang optimal (Ravisankar et al. 2015).

Tabel 3. Kontribusi pangan pada asupan kalsium, vitamin A dan vitamin C pada balita stunting dan normal di 5 provinsi

\begin{tabular}{|c|c|c|c|c|c|c|c|c|c|}
\hline \multirow{2}{*}{$\begin{array}{c}\text { Kelompok } \\
\text { Pangan }\end{array}$} & \multicolumn{3}{|c|}{ Kalsium (mg/orang/hari) } & \multicolumn{3}{|c|}{ Vitamin A (mg/orang/hari) } & \multicolumn{3}{|c|}{ Vitamin C (mg/orang/hari) } \\
\hline & Stunting & Normal & Nilai $p$ & Stunting & Normal & Nilai $p$ & Stunting & Normal & Nilai $p$ \\
\hline Serelia & $148.18 \pm 93.68$ & $151.64 \pm 102.17$ & 0.44 & $57.16 \pm 208.92$ & $50.23 \pm 181.32$ & 0.43 & $0.73 \pm 5.02$ & $0.94 \pm 9.86$ & 0.57 \\
\hline Umbi & $27.54 \pm 45.91$ & $24.32 \pm 32.59$ & 0.32 & $0.08 \pm 0.97$ & $0.00 \pm 0.12$ & 0.19 & $3.33 \pm 11.06$ & $3.26 \pm 9.70$ & 0.93 \\
\hline Kacang & $127.18 \pm 135.93$ & $127.85 \pm 126.47$ & 0.94 & $0.00 \pm 0.00$ & $0.71 \pm 9.67$ & 0.06 & $0.13 \pm 0.54$ & $0.26 \pm 1.92$ & 0.10 \\
\hline Sayur & $47.30 \pm 151.55$ & $34.02 \pm 74.25$ & 0.07 & $0.04 \pm 0.52$ & $0.15 \pm 2.25$ & 0.22 & $14.52 \pm 22.18$ & $11.80 \pm 16.75$ & $0.02^{*}$ \\
\hline Buah & $21.24 \pm 21.73$ & $15.39 \pm 19.56$ & $0.00^{*}$ & $1.77 \pm 17.25$ & $0.55 \pm 12.54$ & 0.38 & $30.91 \pm 50.53$ & $22.59 \pm 34.97$ & $0.05^{\star}$ \\
\hline Daging & $8.31 \pm 10.82$ & $9.99 \pm 18.38$ & 0.07 & $57.62 \pm 118.17$ & $88.68 \pm 343.45$ & $0.04^{*}$ & $0.25 \pm 0.80$ & $0.34 \pm 0.95$ & 0.10 \\
\hline Jeroan & $87.33 \pm 166.76$ & $145.39 \pm 237.35$ & 0.30 & $390.31 \pm 856.39$ & $364.81 \pm 1142.50$ & 0.93 & $0.17 \pm 0.28$ & $0.82 \pm 3.61$ & 0.38 \\
\hline Ikan & $123.89 \pm 299.92$ & $88.63 \pm 223.23$ & 0.12 & $74.68 \pm 169.45$ & $47.11 \pm 91.21$ & $0.03^{*}$ & $0.23 \pm 3.54$ & $0.96 \pm 7.99$ & 0.16 \\
\hline Susu & $417.16 \pm 601.20$ & $450.10 \pm 612.78$ & 0.35 & $607.40 \pm 831.66$ & $650.20 \pm 880.08$ & 0.39 & $18.62 \pm 38.65$ & $22.17 \pm 40.22$ & 0.12 \\
\hline Minyak & $2.58 \pm 7.47$ & $1.96 \pm 6.02$ & 0.06 & $4.06 \pm 16.95$ & $4.57 \pm 19.73$ & 0.56 & $0.23 \pm 0.62$ & $0.17 \pm 0.51$ & 0.06 \\
\hline Gula & $3.13 \pm 7.24$ & $2.37 \pm 4.80$ & $0.03^{*}$ & $0.00 \pm 0.00$ & $0.00 \pm 0.00$ & - & $0.01 \pm 0.20$ & $0.00 \pm 0.05$ & 0.39 \\
\hline Bumbu & $6.02 \pm 9.75$ & $5.93 \pm 8.51$ & 0.83 & $0.01 \pm 0.12$ & $0.01 \pm 0.16$ & 0.73 & $0.89 \pm 2.19$ & $0.81 \pm 1.59$ & 0.33 \\
\hline Minuman & $9.80 \pm 35.23$ & $14.10 \pm 54.96$ & 0.15 & $60.17 \pm 324.44$ & $118.01 \pm 600.01$ & 0.06 & $106.86 \pm 282.19$ & $46.91 \pm 153.56$ & $0.00^{*}$ \\
\hline $\begin{array}{l}\text { Makanan } \\
\text { komposit }\end{array}$ & $46.19 \pm 39.41$ & $61.90 \pm 50.06$ & 0.64 & $15.55 \pm 7.58$ & $21.42 \pm 19.32$ & 0.64 & $0.00 \pm 0.00$ & $0.00 \pm 0.00$ & - \\
\hline Air & $0.00 \pm 0.00$ & $0.00 \pm 0.00$ & - & $0.00 \pm 0.00$ & $0.00 \pm 0.00$ & - & $0.00 \pm 0.00$ & $0.00 \pm 0.00$ & - \\
\hline Suplemen & $0.00 \pm 0.00$ & $0.00 \pm 0.00$ & - & $195.32 \pm 252.52$ & $320.78 \pm 372.43$ & 0.27 & $0.00 \pm 0.00$ & $7.22 \pm 23.97$ & 0.08 \\
\hline
\end{tabular}

Keterangan: *Rata-rata asupan zat gizi antara balita stunting dan normal berbeda secara signifikan $(p<0.05)$ 
Kecukupan asupan zat besi, vitamin A dan C kurang dengan presentase lebih dari $40 \%$ dari total contoh. Kecukupan zat besi yang kurang pada balita stunting 45.52\% dari total contoh balita stunting. Kecukupan asupan vitamin A dan $\mathrm{C}$ yang kurang pada balita stunting masing-masing $56.52 \%$ dan $64.32 \%$ dari total contoh balita stunting. Maggini et al. (2018) menyatakan bahwa konsekuensi negatif dari pola makan yang tidak memadai dengan kepadatan mikronutrien yang tidak mencukupi menyebabkan gangguan pertumbuhan fisik, perkembangan mental dan fungsi kekebalan tubuh, menghasilkan tingkat infeksi yang lebih tinggi.

\section{Keseimbangan asupan zat gizi pada balita di 5 provinsi di Indonesia}

Pada penelitian diperoleh data bahwa antara balita stunting dan balita normal tidak mengonsumsi pangan dengan asupan gizi seimbang. Ketidakseimbangan dengan asupan zat gizi kurang pada balita stunting mencapai $94.38 \%$ sedangkan pada balita normal $89.41 \%$. Ketidakseimbangan dengan asupan zat gizi berlebih pada balita stunting mencapai 5.62\% sedangkan pada balita normal $10.59 \%$. Pada Tabel 5 diketahui juga seiring dengan bertambahnya usia, keseimbangan asupan zat gizi pada balita menurun, sehingga semakin banyak balita dengan gizi tidak seimbang pada usia 1260 bulan. Studi di Afrika Selatan oleh Theron et al. (2007) menunjukkan asupan makanan yang tidak memadai tidak ditemukan menjadi faktor penyebab stunting dan normal. Studi yang dilakukan Sanin et al. (2018) di Bangladesh menemukan kecukupan mikronutrien tidak dapat dijadikan parameter untuk memprediksi secara signifikan antara balita stunting dan balita normal karena kecukupan gizi mikro yang buruk secara keseluruhan terjadi pada balita stunting maupun balita normal pada usia 12-24 bulan. Hal ini menunjukkan bahwa balita yang stunting dan normal yang terlibat dalam penelitian ini mengonsumsi makanan yang kurang gizi hingga tingkat yang sama. Penelitian stunting di Etiopia oleh Motbainor et al.
(2015) menyimpulkan strategi intervensi malnutrisi balita harus difokuskan tidak hanya pada program ketahanan pangan tetapi juga keanekaragaman pangan untuk nutrisi balita, jumlah makanan yang dimakan balita per hari membutuhkan perhatian khusus.

\section{KESIMPULAN}

Balita di lima provinsi yang mengalami stunting sebanyak 38\% dari jumlah contoh. Pada provinsi Jawa Barat, Jawa Tengah, dan Jawa Timur ada 1 balita stunting diantara 3 balita, sedangkan pada provinsi NTT dan NTB ada satu balita stunting diantara dua balita. Konsumsi balita dengan tinggi normal lebih tinggi daripada balita stunting untuk telur dan produk telur dan lebih rendah untuk gula. Asupan kalsium, vitamin A pada balita normal secara signifikan lebih tinggi daripada stunting balita dan lebih rendah untuk vitamin C. Status gizi kurang, cukup, dan berlebih terdapat pada balita stunting dan normal. Asupan gizi yang tidak seimbang pada balita stunting dan normal mencapai $100 \%$.

\section{UCAPAN TERIMA KASIH}

Penulis mengucapkan terimakasih kepada Badan Penelitian dan Pengembangan Kesehatan (Balitbangkes), Kementerian Kesehatan RI atas data Riskesdas 2013 dan SKMI 2014 yang sudah diberikan guna menunjang penelitian ini.

\section{DAFTAR PUSTAKA}

[ASEAN] Association of Southeast Asian Nations. 2014. ASEAN Food Composition Database. ASEAN FOOD Regional Centre and INFOODS Regional Database Centre, Bangkok.

Tabel 4. Sebaran contoh berdasarkan kecukupan zat gizi pada balita di 5 provinsi di Indonesia

\begin{tabular}{|c|c|c|c|c|c|c|c|c|c|}
\hline \multirow{3}{*}{ Zat Gizi } & \multicolumn{9}{|c|}{ Populasi Contoh (Balita) } \\
\hline & \multicolumn{3}{|c|}{ Stunting } & \multicolumn{3}{|c|}{ Normal } & \multicolumn{3}{|c|}{ Jumlah } \\
\hline & Kurang & Cukup & Berlebih & Kurang & Cukup & Berlebih & Kurang & Cukup & Berlebih \\
\hline Energi & 202 & 375 & 205 & 281 & 594 & 381 & 483 & 969 & 586 \\
\hline Karbohidrat & 300 & 320 & 163 & 448 & 500 & 308 & 748 & 820 & 471 \\
\hline Lemak & 282 & 280 & 220 & 406 & 451 & 402 & 688 & 731 & 622 \\
\hline Kalsium & 560 & 84 & 139 & 761 & 171 & 324 & 1321 & 255 & 463 \\
\hline Natrium & 80 & 92 & 611 & 104 & 200 & 952 & 184 & 292 & 1563 \\
\hline Vitamin A & 442 & 73 & 267 & 653 & 112 & 493 & 1095 & 185 & 760 \\
\hline Vitamin C & 503 & 78 & 201 & 834 & 104 & 319 & 1337 & 182 & 520 \\
\hline
\end{tabular}

Tabel 5. Populasi balita stunting dan normal berdasarkan keseimbangan asupan zat gizi di 5 provinsi

\begin{tabular}{|c|c|c|c|c|c|c|}
\hline \multirow{2}{*}{ Status Gizi } & \multirow{2}{*}{ Keseimbangan Zat Gizi } & \multicolumn{4}{|c|}{ Balita pada Umur } & \multirow{2}{*}{ Jumlah } \\
\hline & & 0-5 Bulan & 6-11 Bulan & 12-36 Bulan & 37-60 Bulan & \\
\hline \multirow{3}{*}{ Stunting } & tidak seimbang-kurang & 10 & 29 & 336 & 363 & 738 \\
\hline & tidak seimbang-berlebih & 8 & 6 & 20 & 10 & 44 \\
\hline & seimbang & 0 & 0 & 0 & 0 & 0 \\
\hline \multirow{3}{*}{ Normal } & tidak seimbang-kurang & 63 & 74 & 486 & 499 & 1122 \\
\hline & tidak seimbang-berlebih & 41 & 18 & 43 & 31 & 133 \\
\hline & seimbang & 0 & 0 & 0 & 0 & 0 \\
\hline
\end{tabular}


Burckhardt P, Dawson-Hughes B, Weaver C. 2010. Nutritional Influences on Bone Health. Springer, New York. DOI: 10.1007/978-1-84882-978-7.

Cruz LMG, Azpeitia GG, Súarez DR, Rodríguez AS, Ferrer JFL, Serra-Majem L. 2017. Factors associated with stunting among children aged 0 to 59 months from the Central Region of Mozambique. Nutr 9(5): 491-506.DOI:10.3390/nu9050491.

Dewey GK. 2001. Nutrition, growth, and complementary feeding of breastfed infant. Ped Clin North America 48(1): 87-104. DOI: 10.1016/S00313955(05)70287-X.

Gibson RS, Manger MS, Krittaphol W, Pongcharoen T, Gowachirapant S, Winichagoon P. 2007. Does zinc deficiency play a role in stunting among primary school children in Thailand. Br J Nutr 97(1): 167175. DOI: $10.1017 / \mathrm{S} 0007114507250445$.

Iannotti LL, Lutter CK, Stewart CP, Riofrio CAG, Malo C, Reinhart G, Palacios A, Karp C, Chapnick M, Cox K, Waters WF. 2017. Eggs in early complementary feeding and child growth: a randomized controlled trial. Pediatrics 140(1): e20163459. DOI: 10.1542/ peds.2016-3459.

[Kemenkes] Kesehatan RI. 2020. Peraturan Menteri Kesehatan RI No. 2 tahun 2020 tentang Standar Antropometri Balita. Kemenkes, Jakarta.

[Kemenkes] Kementerian Kesehatan RI. 2013a. Riset Kesehatan Dasar 2013. Kemenkes, Jakarta.

[Kemenkes] Kementerian Kesehatan RI. 2013b. Peraturan Menteri Kesehatan Republik Indonesia No.75 Tahun 2013 tentang Angka Kecukupan Gizi yang Dianjurkan bagi Bangsa Indonesia. Kemenkes, Jakarta.

[Kemenkes] Kementerian Kesehatan RI. 2014. Buku Studi Diet Total: Survei Konsumsi Makanan Individu. Kemenkes, Jakarta.

[Kemenkes] Kementerian Kesehatan RI. 2018. Riset Kesehatan Dasar 2018. Kemenkes, Jakarta.

Maggini S, Pierre A, Calder PC. 2018. Review immune function and micronutrient requirements change over the life course. Nutr 10(10): 1531. DOI: 10.3390/ nu10101531.

McCrory MA, Campbell WW. 2011. Effect of eating frequency, snacking, and breakfast skipping on energy regulation. J Nutr 141(1): 144-147. DOI: 10.3945/jn. 109.114918.

Mikhail WZA, Sabhy HM, El-sayed HH, Khairy SA, Salem HYHA, Samy MA. 2013. Effect of nutritional status on growth pattern of stunted preschool children in Egypt. Acad J Nutr 2(1): 1-9. DOI: 10.5829/ idosi.ajn.2013.2.1.7466.

Motbainor A, Worku A, Kumie A. 2015. Stunting is associated with food diversity while wasting with food insecurity among underfive children in East and West Gojjam Zones of Amhara Region, Ethiopia. PLoS ONE 10(8): e0133542. DOI: 10.1371/journal. pone.0133542.
O’Neil CE, Fulgoni III VL, Nicklas TA. 2011. Association of candy consumption with body weight measures, other health risk factors for cardiovascular disease, and diet quality in US children and ado-lescents: NHANES 1999-2004. Food Nutr Res 55: 5794. DOI:10.3402/fnr.v55i0.5794.

Ravisankar P, Reddy AA, Nagalakshmi B Koushik OS, Kumar BV, Anvith PS. 2015. The comprehensive review on fat soluble vitamins. IOSR J Pharm 5(11): 12-28.

Sanin KI, Islam MM, Mahfuz M, Ahmed AMS, Mondal D, Haque R, Ahmed T. 2018. Micronutrient adequacy is poor, but not associated with stunting between 12-24 months of age: A cohort study findings from a slum area of Bangladesh. PLoS ONE 13(3): $\quad$ e0195072. 10.1371/journal.pone.019 5072.

Sari EM, Juffrie M, Nurani N, Sitaresmi MN. 2018. Asupan protein, kalsium dan fosfor pada balita stunting dan tidak stunting usia $24-59$ bulan. J Gizi Klinik Indonesia 12(4): 152-159. DOI: 10.22146/ ijen.23111.

Ssentongo P, Ba DM, Ssentongo AE, Fronterre C, Whalen A, Yang Y, Ericson JE, Chinchilli VM. 2020. Association of vitamin A deficiency with early childhood stunting in Uganda: A populationbased cross-sectional study. PLoS ONE 15(5): e0233615. DOI: 10.1371/journal. pone.0233615.

Stuijvenberg ME, Nel J, Schoeman SE, Lombard CJ, du Plessis LM, Dhansay MA. 2015. Low intake of calcium and vitamin $\mathrm{D}$, but not zinc, iron or vitamin $A$, is associated with stunting in 2-5 years old children. Nutr 31: 841-846. DOI: 10.1016/j.nut.2014. 12.011.

Theron M, Amissah A, Kleynhans I, Albertse E, MacIntyre U. 2007. Inadequate dietary intake is not the cause of stunting amongst young children living in an informal settlement in Gauteng and rural Limpopo Province in South Africa: the NutriGro study. Pub Health Nutr 10: 379-389. DOI:10.1017/ S1368980007246579.

[TNP2K] Tim Nasional Percepatan Penanggulangan Kemiskinan. 2017. 100 Kota/Kabupaten Prioritas Untuk Inversi Balita Kerdil (Stunting). TNP2K, Jakarta.

Valentina V. 2014. Kontribusi Pangan Terhadap Asupan dan Status Gizi Kalsium dan Vitamin D pada Balita Indonesia Usia 2 sampai dengan 12 Tahun. [Tesis]. Bogor: Sekolah Pascasarjana, Institut Pertanian Bogor.

[WHO] World Health Organization. 2014. Global Nutrition Target 2025: Stunting Policy Brief. Geneva: WHO.

JMP-07-20-10-Naskah diterima untuk ditelaah pada 7 Agustus 2020. Revis makalah disetujui untuk dipublikasi pada 12 September 2020. Versi Online: http://journal.ipb.ac.id/index.php/jmpi 